\title{
Evaluation of a standard protocol for drying off and drying off therapy in dairy cows based on the comparison of two different commercial antimicrobials
}

\author{
Luca Turini ${ }^{1 *}$, Filippo Fratini ${ }^{1,2}$, Giuseppe Conte ${ }^{3}$, Barbara Turchi ${ }^{1}$, Domenico Cerri ${ }^{1,2}$, \\ Fabrizio Bertelloni ${ }^{1}$, and Francesca Bonelli ${ }^{1}$ \\ ${ }^{1}$ Department of Veterinary Science, University of Pisa, Pisa, Italy \\ ${ }^{2}$ Interdepartmental Research Center "Nutraceuticals and Food for Health", University of Pisa, Pisa, Italy \\ ${ }^{3}$ Department of Agricultural, Food and Agro-Environmental Science, University of Pisa, Pisa, Italy
}

TURINI, L., F. FRATINI, G. CONTE, B. TURCHI, D. CERRI, F. BERTELLONI, F. BONELLI: Evaluation of a standard protocol for drying off and drying off therapy in dairy cows based on the comparison of two different commercial antimicrobials. Vet. arhiv 90, 217-224, 2020.

\section{ABSTRACT}

This study aims to evaluate two commercial antibiotics for drying off. Ninety-five Friesian cows and 380 quarters were included. The cows were classified as Control or Subclinical Mastitis based on somatic cell count. The California Mastitis Test and the teat end score were performed. Quarters were randomly treated with Cloxacillin and Ampicillin (TA) or Cephalexin (TB). The effect of the therapy (TA vs. TB) was estimated by $\mathrm{X} 2$ analysis based on the Wald test. The preservative and therapeutic actions of TA vs. TB were evaluated by the Kruskall-Wallis test. TB showed a statistically significant therapeutic effect in the control group, that might be related to the pharmacological activity of the two antibiotics. Also, the subclinical mastitis group most commonly presented more quarters affected compared to the control group, leading to worse improvement despite proper therapy. In conclusion, in abrupt drying off, the California mastitis test, teat end score and somatic cell count evaluation, as well as microbial herd data, might represent key concepts for an efficient drying off standard protocol on a dairy farm. In line with the herd bacterial population, both TA and TB may be employed for drying off therapy.

Key words: veterinary; dairy cow; mastitis; dry period; drying-off therapy

\section{Introduction}

The dry period is defined as the non-lactating period prior to parturition in dairy cows. Usually, this period begins at the end of the lactation curve, whose shape and length are strongly influenced by several environmental and genetic factors (MACCIOTTA et al., 2011). The length of the dry

period is about 60 days in Europe and the United States of America (ANNEN et al., 2004). The dry period has a critical role for udder health, due to the increased risk of intra-mammary infections (IMI) during this time (BRADLEY and GREEN, 2000; WHIST and ØSTERAS, 2007). Despite

\footnotetext{
*Corresponding author:

Dr. Luca Turini, Dipartimento di Scienze Veterinarie, Viale delle Piagge 2, 56122, Pisa, Italy, Phone: +39 0502210 115; Fax: +39 0502210654 ; E-mail: luca.turini@phd.unipi.it
} 
good dry period management, some animals appear more prone to new IMI than others, and may show clinical mastitis in the next lactation (HOGAN and SMITH, 2003). The most frequently isolated microorganisms during drying off are Streptococcus spp., coagulase-negative staphylococci (CNS), Staphylococcus aureus and Corynebacterium spp. (PANTOJA et al., 2009; MAĆEŠIĆ et al., 2012). Dry cow therapy (DCT) is an intra-mammary treatment with an antibiotic, administered at the beginning of the dry period. For many years, the treatment of IMI during drying off has been a basis for mastitis control and management (BRADLEY and GREEN 2000, BENIĆ et al., 2018). Dry cow therapy eliminates existing IMI, and prevents new ones (BRADLEY and Green 2000; WHIST and ØSTERAS, 2007). The elimination of infection and the prevention of new IMIs in the dry period is easier than during lactation. The drug is not milked out, so the antibiotic remains longer in the udder. Moreover, the absence of regular milking reduces the exposure to pathogens through teat penetration (KASHIF et al., 2016).

Themostcommondrugs used as drying off therapy are intra-mammary tubes, containing antibiotics such as penicillin, cloxacillin, cephalosporin and spiramycin (KASHIF et al., 2016). Despite the large amount of literature about drying off therapy strategies, the decision concerning which antibiotic therapy would be better in a specific herd is still usually made on the basis of drug popularity and the farmer's preference, and not scientific evidence.

The aim of the present study was to evaluate the effects on the mammary microbiological populations of two different commercial antibiotics during drying off in the same herd, in order to set a standard protocol for dry cow therapy acording to the bacteria isolated.

\section{Materials and methods}

Animals. The present study was carried out on an intensive dairy farm located in the north of Italy. A total of 108 Italian Holstein Friesian cows, under the same management conditions, were considered for the trial. The owner's written consent for participating in the study was received. All the experimental procedures were in compliance with the 2010/63/UE directive about the protection of animals in scientific experiments.

The cows were between 210 and 220 days of gestation and were considered healthy on the basis of a complete physical examination. The animals included in the trial had not been subjected to antibiotic and/or nonsteroidal anti-inflammatory drugs (NSAIDs) treatment for a 30 day period before the admission time, and did not show udder or milk abnormalities at drying off. All the animals included were observed from drying off until 15 days of lactation. The standard drying off protocol proposed in this study was carried out as follows: All eligible cows were dried off abruptly. During the last milking session, the teat end score (TESa) was recorded for each quarter, as reported in literature (NEIJENHUIS et al., 2000), along with the udder evaluation. The California Mastitis Test (CMTa) was used as the screening test for detection of subclinical mastitis (BARNUM and NEWBOULD 1961). A sample was considered positive at CMT $\geq 1$ (BLOWEY and EDMONDSON 2010). Before the antibiotic administration, a sterile milk sample was collected for bacteriologic analysis from positive CMT quarters in $15 \mathrm{~mL}$ tubes (Falcon ${ }^{\circledR}, \mathrm{BD}$, Italy), and stored at $4{ }^{\circ} \mathrm{C} \pm 2{ }^{\circ} \mathrm{C}$ until the time of analysis. All the samples were processed within 3 hours. After these evaluations, the animals were treated with Cloxacillin and Ampicillin (Cloxalene Max, Fatro, Italy), or Benzathine Cephalexin (Rilexine, $500 \mathrm{HL}$, Virbac, Italy) as dry cow therapy, regardless of the CMT results. Drying off cows were then transferred to a separate box, located in a different barn. The dry cow boxes were constructed like pens for daily exercise, with a the feeding area in between, where all the animals were fed at the same time. Moreover, there was a resting zone in this area, composed of an appropriate number of cubicles bedded with straw that was changed on a daily basis. At dryingoff, the cows were fed a low energy density diet, administered as total mixed ration (TMR) twice a day. At the inclusion time, the animals were divided into two groups (Treatment A and Treatment B) based on the drug supply on the farm. Treatment A (TA) quarters received $600 \mathrm{mg}$ of Cloxacillin and $300 \mathrm{mg}$ of Ampicillin (Cloxalene Max, Fatro, Italy), while treatment B (TB) quarters received 
$375 \mathrm{mg}$ of Benzathine Cephalexin (Rilexine, 500 HL, Virbac, Italy). All 4 quarters of a single cow were treated with the same antibiotics. For the sake of the better classification of the cows, the average somatic cell count (SCCa) of the 4 quarters was evaluated at the inclusion time by a MilkoScan (FOSS, Italy). Thus, animals were retrospectively classified as "C cows" when the SCC was $<150,000$ cells $/ \mathrm{mL}$ for primiparous and $<250,000$ cells $/ \mathrm{mL}$ for multiparous cows, and as "SCM cows" when the SCC was $>150,000$ cells $/ \mathrm{mL}$ for primiparous and $>$ 250,000 cells/mL for multiparous cows (DE HAAS et al., 2008; WINDIG et al., 2010). The "C cows" were considered as the control animals. A second evaluation took place 15 days after parturition for each quarter included. The same parameters as were collected at the inclusion time were considered: 1) teat end score for each quarter (TESb); 2) CMT was performed for each quarter 15 days after parturition (CMTb); 3) the average SCC (SCCb) of each single quarter was calculated.

Bacteriology analysis. To isolate the mastitis agents and to screen the microbial population of the studied herd, $0.01 \mathrm{~mL}$ of each CMT positive milk sample was streaked on blood agar plates containing $10 \%$ sheep blood. Each plate was incubated aerobically at $37{ }^{\circ} \mathrm{C}$ for $24-48 \mathrm{~h}$. After observation of colony morphology and hemolytic patterns on the blood agar, the isolates were submitted to Gram staining, catalase and oxidase testing, and additional biochemical and metabolic evaluations as needed.

Gram-negative organisms were successively identified by sowing on appropriate selective and differential media; furthermore, enzyme activities, acid production from different carbohydrates, and assimilation of various substrates were determined using the commercial systems API ZYM, API 20E and API 20NE (BioMerieux ${ }^{\circledR}$ ), according to the manufacturer's instructions.

Staphylococcus spp., grown on Baird Parker medium with the typical halo associated with lecithinase positivity, and characterized by typical zones of complete and incomplete hemolysis and nonhemolytic Staphylococcus spp., with a positive tube test for free coagulase, were classified as Staphylococcus aureus. All other staphylococci were classified as CNS. Moreover, all isolates belonging to the Staphylococcus genus were also identified using API Staph $\left(\right.$ BioMerieux $\left.^{\circledR}\right)$. The other Gram-positive cocci, grown on blood agar plates, and negative in the catalase test, were phenotypically identified by means of API 20 Strep $\left(\right.$ BioMerieux $^{\circledR}$ ).

Statistical analysis. Data concerning SCCa and $\mathrm{SCCb}, \mathrm{CMTa}$ and CMTb, type of treatment (TA vs TB) and the TESa and TESb of the C and SCM groups, were expressed as prevalence.

Data obtained in this work were analyzed using $\mathrm{R}$ software (R Development Core Team). Firstly, the effect of the therapy (use of the antibiotics TA or TB) on the number of positive or negative teats to CMTa were estimated by c2 analysis, based on the Wald test. The analysis was repeated both for cows classified as "C" and "SCM".

Subsequently, we estimated the different effect of the two antibiotics by the non-parametric Kruskall-Wallis test. This analysis was repeated in two different situations: first, we evaluated the protective action of the two antibiotics considering the percentage of negative CMT teats that remain unchanged after the treatment; while the therapeutic effect was estimated considering the percentage of positive CMT teats that became negative after treatment.

\section{Results}

A total of 380 quarter in 95 cows were included, from 46 primiparous cows (48\%) and 49 multiparous cows (52\%). Thirteen animals of the 108 enrolled were excluded from the study due to the presence of only three functional udder quarters or because they had undergone treatments over the 30 days before the inclusion time. Cows were in first to fifth lactation, at an average of 4.5 (37) years old, with average body weight of $660 \mathrm{~kg}$ (520-710) and average body condition score (BCS) of 3.25 (2.5-3.75).

One hundred and thirty-six/380 quarters (in 34 cows) received TA, while 244/380 quarters (61 cows) were treated with TB. On the basis of SCCa evaluation, a total of 29 cows (18 primiparous and 11 multiparous) were included in the $\mathrm{C}$ group, while 66 cows (28 primiparous and 38 multiparous) were 
included in the SCM group. A total of 32 quarters belong to the $\mathrm{C}$ group were treated with TA, while 84 quarters were treated with TB. A total of 104 quarters belonging to the SCM group were treated with TA, while 160 quarters were treated with TB. Data concerning the SCCa, CMTa and TESa of C and SCM groups are presented in Table 1.

A total of 68 of 380 milk samples were CMTa positive, thus they were sampled for bacteriologic analysis. Fifty-three out of 68 milk samples (78\%) were culture negative, nine $(13 \%)$ were positive for environmental pathogens (CNS and Serratia), while the remaining 6 samples $(9 \%)$ were positive for contagious pathogens. The $\mathrm{pH}$ was outside the normal range (6.5-6.7) in 41 out of $68(60 \%)$ milk samples (RUEGG and ERSKINE, 2015). The average $\mathrm{pH}$ value was $6.8 \pm 0.2$.

Results concerning CMTb and TESb of $\mathrm{C}$ and $\mathrm{SCM}$ cows, grouped on the basis of SCCa are reported in Table 2, while the results concerning $\mathrm{CMTb}$ and TESb of C and SCM cows, grouped on the basis of $\mathrm{SCCb}$ are reported in Table 3.
Results concerning changes between CMTa vs $\mathrm{CMTb}$ in TA vs. TB cows, classified on the basis of SCCa are reported in Table 4.

Table 5 shows the result of contingency analysis related to the number of quarters treated with TA and TB. Statistical differences between the expected and observed number of quarters were revealed for SCM cows $(\mathrm{P}<0.001)$, with a higher number of positive quarters observed for TA.

The results concerning the effect of the different antibiotics on quarters as prevention (expressed as $\%$ of quarters that continued to be CMT negative after treatment), and therapy (expressed as \% of quarters that were CMT negative after treatment) are reported in Table 6. A different effect between the two treatments was only observed for the $\mathrm{C}$ cows $(\mathrm{P}=0.022)$ as part of the therapeutic action, while no difference was revealed for SCM cows (P $=0.990)$. On the contrary, the preventive effect was similar for both TA and TB.

Table 1. Data concerning the evaluation of SCCa, CMTa and TESa scores performed in C and SCM groups

\begin{tabular}{|c|c|c|c|c|c|c|c|c|c|}
\hline \multirow{2}{*}{$\begin{array}{l}\mathrm{SCCa} \\
\text { (cell/mL) }\end{array}$} & \multirow[b]{2}{*}{ CMTa } & \multicolumn{2}{|c|}{ TESa score 1} & \multicolumn{2}{|c|}{ TESa score 2} & \multicolumn{2}{|c|}{ TESa score 3} & \multicolumn{2}{|c|}{ TESa score 4} \\
\hline & & TA & TB & TA & TB & TA & TB & TA & TB \\
\hline \multirow{2}{*}{$\mathrm{C}$ group } & Positive & $1 / 32$ & $0 / 84$ & $2 / 32$ & $4 / 84$ & $0 / 32$ & $2 / 84$ & $0 / 32$ & $0 / 84$ \\
\hline & Negative & $26 / 32$ & $68 / 84$ & $3 / 32$ & $10 / 84$ & $0 / 32$ & $0 / 84$ & $0 / 32$ & $0 / 84$ \\
\hline \multirow{2}{*}{$\begin{array}{l}\text { SCM } \\
\text { group }\end{array}$} & Positive & $11 / 104$ & $4 / 160$ & $17 / 104$ & $14 / 160$ & $2 / 104$ & $8 / 160$ & $0 / 104$ & $3 / 160$ \\
\hline & Negative & $54 / 104$ & $94 / 160$ & $19 / 104$ & $32 / 160$ & $1 / 104$ & $3 / 160$ & $0 / 104$ & $2 / 160$ \\
\hline
\end{tabular}

SCCa - somatic cells count at inclusion time (drying-off); CMTa - california mastitis test at inclusion time (drying-off); TESa - teat score for each quarter; TA - treatment A (600 mg of Cloxacillin and $300 \mathrm{mg}$ of Ampicillin); TB - treatment B (375mg of Benzathine Cephalexin); C group - control group; SCM group - subclinical mastitis group.

Table 2. Data concerning the evaluation of CMTb and TESb scores performed in C and SCM grouped based on $\mathrm{SCCa}$

\begin{tabular}{|c|c|c|c|c|c|c|c|c|c|}
\hline \multirow{2}{*}{$\begin{array}{c}\mathrm{SCCa} \\
(\mathrm{cell} / \mathrm{mL})\end{array}$} & \multirow[b]{2}{*}{$\mathrm{CMTb}$} & \multicolumn{2}{|c|}{ TESb score 1} & \multicolumn{2}{|c|}{ TESb score 2} & \multicolumn{2}{|c|}{ TESb score 3} & \multicolumn{2}{|c|}{ TESb score 4} \\
\hline & & TA & TB & TA & TB & TA & TB & TA & TB \\
\hline \multirow{2}{*}{$\mathrm{C}$ group } & Positive & $3 / 32$ & $1 / 84$ & $1 / 32$ & $3 / 84$ & $0 / 32$ & $0 / 84$ & $0 / 32$ & $0 / 84$ \\
\hline & Negative & $24 / 32$ & $67 / 84$ & $4 / 32$ & $11 / 84$ & $0 / 32$ & $2 / 84$ & $0 / 32$ & $0 / 84$ \\
\hline \multirow{2}{*}{$\begin{array}{l}\text { SCM } \\
\text { group }\end{array}$} & Positive & $6 / 104$ & $3 / 160$ & $5 / 104$ & $8 / 160$ & $1 / 104$ & $3 / 160$ & $0 / 104$ & $1 / 160$ \\
\hline & Negative & $59 / 104$ & $95 / 160$ & $31 / 104$ & $38 / 160$ & $2 / 104$ & $8 / 160$ & $0 / 104$ & $4 / 160$ \\
\hline
\end{tabular}

SCCa - somatic cells count at inclusion time (drying-off); CMTb - california mastitis test 15 days after parturition; TA - treatment A (600 mg of Cloxacillin and $300 \mathrm{mg}$ of Ampicillin); TB - treatment B (375 mg of Benzathine Cephalexin); C group - control group; SCM group - subclinical mastitis group. 
Table 3. Data concerning the evaluation of CMTb and TESb scores performed in C and SCM groups based on SCCb.

\begin{tabular}{|c|c|c|c|c|c|c|c|c|c|}
\hline \multirow{2}{*}{$\begin{array}{l}\mathrm{SCCb} \\
(\text { cell } / \mathrm{mL})\end{array}$} & \multirow[b]{2}{*}{ CMTb } & \multicolumn{2}{|c|}{ TESb score 1} & \multicolumn{2}{|c|}{ TESb score 2} & \multicolumn{2}{|c|}{ TESb score 3} & \multicolumn{2}{|c|}{ TESb score 4} \\
\hline & & TA & TB & TA & TB & TA & TB & TA & TB \\
\hline \multirow{2}{*}{$\mathrm{C}$ group } & Positive & $1 / 136$ & $1 / 244$ & $4 / 136$ & $0 / 244$ & $0 / 136$ & $0 / 244$ & $0 / 136$ & $0 / 244$ \\
\hline & Negative & $72 / 136$ & $120 / 244$ & $23 / 136$ & $38 / 244$ & $2 / 136$ & $7 / 244$ & $0 / 136$ & $2 / 244$ \\
\hline \multirow{2}{*}{$\begin{array}{l}\text { SCM } \\
\text { group }\end{array}$} & Positive & $6 / 136$ & $9 / 244$ & $5 / 136$ & $5 / 244$ & $1 / 136$ & $3 / 244$ & $0 / 136$ & $2 / 244$ \\
\hline & Negative & $13 / 136$ & $36 / 244$ & 9/136 & $17 / 244$ & $0 / 136$ & $3 / 244$ & $0 / 136$ & $1 / 244$ \\
\hline
\end{tabular}

$\mathrm{SCCb}$ - somatic cells count 15 days after parturition; CMTb - california mastitis test 15 days after parturition; TA - treatment A (600 mg of Cloxacillin and $300 \mathrm{mg}$ of Ampicillin); TB - treatment B (375 mg of Benzathine Cephalexin); C group - control group; SCM group - subclinical mastitis group.

Table 4. Results concerning changes in CMTa vs CMTb for the quarters belonging to C and SCM group based on the treatments received (TA vs TB)

\begin{tabular}{|l|c|c|c|c|c|}
\hline & $\begin{array}{c}\text { Treatment at } \\
\text { drying-off }\end{array}$ & $\begin{array}{c}\text { CMTa-neg } v s \\
\text { CMTb-neg }\end{array}$ & $\begin{array}{c}\text { CMTa-neg } v s \\
\text { CMTb-pos }\end{array}$ & $\begin{array}{c}\text { CMTa-pos } v s \\
\text { CMTb-neg }\end{array}$ & $\begin{array}{c}\text { CMTa-pos } v s \\
\text { CMTb-pos }\end{array}$ \\
\hline \multirow{2}{*}{ C group } & TA & 27 & 2 & 1 & 2 \\
\hline \multirow{2}{*}{ SCM group } & TB & 74 & 4 & 6 & 23 \\
\cline { 2 - 6 } & TA & 69 & 5 & 24 & 7 \\
\hline
\end{tabular}

SCCa - somatic cells count at inclusion time (drying off); CMTa - California mastitis test at inclusion time (drying off); CMTb California mastitis test 15 days after parturition; TA - treatment A (600 mg of Cloxacillin and $300 \mathrm{mg}$ of Ampicillin); TB - treatment B (375 mg of Benzathine Cephalexin); C group - control group; SCM group - subclinical mastitis group.

Table 5. Table of contingency for the estimation of antibiotic treatment effect. The data refers to the number of treated quarters. A) C cows; B) SCM cows

\begin{tabular}{|c|c|c|c|c|c|c|c|}
\hline \multicolumn{8}{|c|}{ A) $P=0.297$} \\
\hline \multicolumn{4}{|c|}{ Observed } & \multicolumn{4}{|c|}{ Expected } \\
\hline & TA & TB & Total & & TA & $\mathrm{TB}$ & Total \\
\hline Positive & 3 & 6 & 9 & Positive & 4 & 5 & 9 \\
\hline Negative & 29 & 78 & 107 & Negative & 28 & 79 & 107 \\
\hline Total & 32 & 84 & 116 & Total & 32 & 84 & 116 \\
\hline \multicolumn{8}{|c|}{ B) $\mathrm{P}<0.001$} \\
\hline \multicolumn{4}{|c|}{ Observed } & \multicolumn{4}{|c|}{ Expected } \\
\hline & $\mathrm{TA}$ & $\mathrm{TB}$ & Total & & $\mathrm{TA}$ & $\mathrm{TB}$ & Total \\
\hline Positive & 30 & 29 & 59 & Positive & 23 & 36 & 59 \\
\hline Negative & 74 & 131 & 205 & Negative & 81 & 124 & 205 \\
\hline Total & 104 & 160 & 264 & Total & 104 & 160 & 264 \\
\hline
\end{tabular}




\section{Turini et al.: Drying off therapy in a dairy farm}

Table 6. Effect of the different antibiotics on teat in a preventive (expressed as \% of quarters that remain negative after treatment) and therapy (expressed as \% of quarters that become negative after treatment)

\begin{tabular}{|l|c|c|c|c|}
\hline & TA & TB & SE & P-value \\
\hline Preventive effect in "C cows" & $92.85 \%$ & $94.91 \%$ & 6.08 & 0.760 \\
\hline Preventive effect in "SCM cows" & $92.68 \%$ & $92.37 \%$ & 4.14 & 0.770 \\
\hline Therapeutic effect in "C cows" & $50.00 \%$ & $100.00 \%$ & 14.56 & 0.022 \\
\hline Therapeutic effect in "SCM cows" & $76.61 \%$ & $81.60 \%$ & 15.84 & 0.990 \\
\hline
\end{tabular}

\section{Discussion}

The dry period is crucial for two different reasons: 1) high rates of IMI healing during this period and 2) the development rates of new IMIs during this period are higher than during the lactating period (HALASA et al., 2009). For these reasons, intramammary antibiotics are used to treat any existing IMIs at drying-off, and to prevent new IMIs during the dry period. However, the choice of the best antibiotic therapy should be set according to the kind of mammary pathogens. Prudent use of antibiotics is recommended to prevent the development of antimicrobial resistance. The isolation of different pathogens, and their sensitivity or resistance to some antibiotics is the key to the choice of the most suitable antibiotics to avoid antimicrobial resistance (SCHERPENZEEL et al., 2014; DJURICIC et al., 2014). The whole population in this study presented no udder or milk abnormalities at drying-off, but only CMT alterations, with a prevalence of subclinical mastitis of $18 \%$, which is a slightly lower value compared with the data reported in the literature (GIANNEECHINI et al., 2002). However, our study only evaluated cows at drying-off, while the data presented in the literature usually came from screening the whole herd. This might explain the differences in results. The reported prevalence of infection at drying off, due to any pathogen, ranges from $28 \%$ to $50 \%$ at cow level (BROWNING et al., 1994). Our results are slightly lower compared with other authors. However, the incidence of infections at drying off in a herd could be influenced by many factors, and this might explain the differences found in prevalence (TORRES et al., 2008).

Otherwise, the high prevalence of subclinical mastitis obtained in this study confirmed that subclinical mastitis still represents an important problem in the dairy cow industry (PISONİ, 2007). Thus, screening for subclinical mastitis at the time of drying-off is mandatory for maintaining a high standard of udder and milk health and hygiene.

The screening method chosen in the present study was CMT because it still represents the one most commonly used in the field (RUEGG and ERSKINE, 2015). Also, the literature recommended the use of CMT for identification of IMI when the herd prevalence of IMI is lower than $15 \%$ (TORRES et al., 2008). The authors knew the average prevalence of IMI from the history of the herd. However, samples that were CMT positive were tested for $\mathrm{BE}$, and the prevalence of positive BE was $22 \%$. Although CMT is largely used in dairy practice, our results confirmed the very high sensitivity of the test (BRADLEY et al., 2012; ZECCONI and ZANIRATO, 2013; SGORBINI et al., 2014). CMT may be influenced by several factors, i.e. the time of sampling (morning vs. evening) or the season (summer vs. autumn) (BRADLEY et al., 2012; ZECCONI and ZANIRATO, 2013), the storage and processing of the samples (BRADLEY et al., 2012), udder inflammation other than infectious problems (i.e. trauma, alimentary management, milking procedures) (ZECCONI and ZANIRATO, 2013). Thus, for a more proper use of antibiotic therapy at drying-off, the BE might be considered to be the gold standard test to drive decisions (RUEGG and ERSKINE, 2015; CVETNIĆ et al., 2016). Staphylococcus spp. was the most common bacterium isolated in our population, as confirmed by the literature (TORRES et al., 2008; ZECCONI and ZANIRATO, 2013; RUEGG and ERSKINE, 2015). Compared with TA, TB showed a statistically significant therapeutic effect in " $\mathrm{C}$ 
cows" while no difference was observed for "SCM cows". Cloxacillin (TA) represents one of the most widely used antibiotics for drying off in dairy cows (HALASA et al., 2009; BHUTTO et al., 2011). However, Cephalexin (TB) has been successfully used in the treatment of subclinical mastitis in lactating cows (TIWARI et al., 2000). The difference in therapeutic effect found in the present study might be related to the pharmacological activity of the two antibiotics. Also, "SMC cows" most commonly had more quarters affected than "C cows", leading to poorer improvement despite proper therapy. Further studies with a higherd number of animals included might supplement the present findings.

\section{Conclusions}

In conclusion, an abrupt drying off, the CMT, TEC and SCC evaluations, as well as microbiological examination might represent key concepts for an efficient standard drying off protocol on a dairy farm. The SCC evaluation is essential to find subclinical mastitis, and to decide on treatment for a single quarter of the udder. The isolation of pathogens before the drying off is the key to choosing the ideal antimicrobial to treat it. In line with the herd bacterial population, both TA and TB might be employed for drying off therapy.

\section{Conflict of interes}

This research did not receive any specific grant from funding agencies in the public, commercial, or not-for-profit sectors.

\section{Acknowledgement}

We wish to thank Dr Anna Paola Biagi for the indispensable linguistic assistance provided.

\section{References}

ANNEN, E. L., R. J. COLLIER, M. A. MCGUIRE, J. L. VICINI, J. M. BALLAM, M. J. LORMORE (2004): Effect of modified dry period lengths and bovine somatotropin on yield and composition of milk from dairy cows. J. Dairy Sci. 87, 3746-3761.

DOI: $10.3168 /$ jds.S0022-0302(04)73513-4

BARNUM, D. A., F. H. S. NEWBOULD (1961): The use of the California Mastitis Test for the detection of bovine mastitis. Can. Vet. J. 2, 83-90.

BENIĆ, M., N. MAĆEŠIĆ, L. CVETNIĆ, B. HABRUN, Ž. CVETNIĆ, R. TURK, D. ĐURIČIĆ, M. LOJKIĆ, V.
DOBRANIĆ, H. VALPOTIĆ, J. GRIZELJ, D. GRAČNER, J. GRBAVAC, M. SAMARDŽIJA (2018): Bovine mastitis: a persistent and evolving problem requiring novel approaches for its control - a review. Vet. arhiv 88, 535557.

DOI: $10.24099 /$ vet.arhiv.0116

BHUTTO, A. L., R. D. MURRAY, Z. WOLDEHIWET (2011): The effect of dry cow therapy and internal teat-sealant on intra-mammary infections during subsequent lactation. Res. Vet. Sci. 90, 316-320.

DOI: $10.1016 /$ j.rvsc.2010.06.006

BLOWEY, R., P. EDMONDSON (2010): Somatic cell count. In: Mastitis control in Dairy Herds (BLOWEY, R., P. Edmondson P, Eds.), $2^{\text {nd }}$ ed., CABI, UK, pp. 153-170.

BRADLEY, A. J., M. J. GREEN (2000): A study of the incidence and significance of intramammary enterobacterial infections acquired during the dry period. J. Dairy Sci. 83, 1957-1965.

DOI: $10.3168 /$ jds.S0022-0302(00)75072-7

BRADLEY, A., H. BARKEMA, A. BIGGS, M. GREEN, T. LAM (2012): Control of mastitis and enhancement of milk quality. In: Dairy Herd Health (Green, D., Eds), CABI, UK, pp. 117-168.

BROWNING, J. W., G. A. MEIN, P. BRIGHTLING, T. J. NICHOLLS, M. BARTON (1994): Strategies for mastitis control: dry cow therapy and culling. Aust. Vet. J. 71, 179181 .

DOI: 10.1111/j.1751-0813.1994.tb03383.x

CVETNIĆ, L., M. SAMARDŽIJA, B. HABRUN, G. KOMPES, M. BENIĆ (2016): Microbiological monitoring of mastitis pathogens in the control of udder health in dairy cows. Slov. Vet. Res. 53, 131-140.

DE HAAS, Y., W. J. OUWELTJES TEN NAPEL, J. J. WINDIG, G. DE JONG (2008): Alternative somatic cell count traits as mastitis indicators for genetic selection. J. Dairy Sci. 91, 2501-2511.

DOI: $10.3168 /$ jds.2007-0459

DJURICIC, D., M. SAMARDZIJA, J. GRIZELJ, T. DOBRANIC (2014): Effect of intramammary treatment of bovine subclinical mastitis during lactation on small and middle scale farms in northwestern Croatia. Annal Med. Vet. 158, 121-125 (In French).

GIANNEECHINI, R., C. CONCHA, R. RIVER, I. DELUCCI, J. MORENO LOPEZ (2002): Occurrence of clinical and subclinical mastitis in dairy herds in the west littoral region in Uruguay. Acta Vet. Scand. 43, 221-230.

DOI: $10.1186 / 1751-0147-43-221$

HALASA, T., O. OSTERAS, H. HOGEVEEN, T. VAN WERVEN, T. NIELEN (2009) Meta-analysis of dry cow management for dairy cattle. Part1. Protection against new intramammary infections. J. Dairy Sci. 92, 3134-3149.

DOI: $10.3168 /$ jds.2008-1740 
HOGAN, J. S., K. L. SMITH (2003): Coliform mastitis. Vet. Res. 34, 507-519.

DOI: $10.1051 /$ vetres:2003022

KASHIF, M., M. RIZWAN, M. ALI, T. AHMAD, A. Z. DURRANI (2016): Control of mastitis through dry cow therapy: a review. Veterinaria 2, 13-16.

MACCIOTTA, N. P. P., C. DIMAURO, S. P. G. RASSU, G. STERI, G. PULINA (2011): The mathematical description of lactation curves in dairy cattle. Ital. J. Anim. Sci. 10:51.

DOI: 10.4081/ijas.2011.e51

MAĆEŠIĆ, N., T. KARADJOLE, G. BAČIĆ, M. BENIĆ, M. KARADJOLE, S. VINCE, M. LIPAR, M. CERGOLJ (2012): Aetiology and prevalence of bovine intramammary infection at drying off. Vet. arhiv 82, 125-131.

NEIJENHUIS, F., H. W. BARKEMA, H. HOGEVEEN, J. P. NOORDHUIZEN (2000): Classification and longitudinal examination of callused teat ends in dairy cows. J. Dairy Sci. 83, 2795-2804.

DOI: $10.3168 /$ jds.S0022-0302(00)75177-0

PANTOJA, J. C. F., C. HULLAND, P. L. RUEGG (2009): Dynamics of somatic cell counts and intramammary infections across the dry period. Prev. Vet. Med. 90, 43-54. DOI: 10.1016/j.prevetmed.2009.03.012

PİSONI, G. (2007): Mastitis in a dairy herd (Point Veterinaire Italie, La fenice grafica, Eds.), Borghetto Lodigiano (Lo), Italy (in Italian).

RUEGG, P. L., R. J. ERSKINE (2015): Mammary gland health. In: Large Animal Internal Medicine (Smith, B. P., Ed.), $5^{\text {th }}$ ed., Elsevier. St Louis, pp. 1015-1043.
SCHERPENZEEL, C. G. M., I. E. M. DEN UIJL, G. VAN SCHAIK, R. G. M. OLDE RIEKERINK, J. M. KEURENTJES, T. J. G. M. LAM (2014) Evaluation of the use of dry cow antibiotics in low somatic cell count cows. J. Dairy Sci. 97, 3606-3614.

DOI: $10.3168 /$ jds.2013-7655

SGORBINI, M., F. BONELLİ, F. FRATINI, A. SBRANA, M. BROMBIN, V. MEUCCI, M. CORAZZA, V. EBANI, F. BERTELLONI, B. TURCHI, D. GATTA, D. CERRI (2014): Mastitis in dairy cattle: a comparison of some screening tests and bacteriology. Large Anim. Rev. 20, 9-16.

TORRES, A. H., P. J. RAJALA-SCHULTZ, F. J. DEGRAVES, K. H. HOBLET (2008): Using dairy herd improvement records and clinical mastitis history to identify subclinical mastitis infections at dry-off. J. Dairy Res. 75, 240-247.

DOI: $10.1017 / \mathrm{S} 0022029908003257$

TIWARI, A., R. S. SISODIA, K. S. MISRAULIA (2000): Treatment of subclinical mastitis in cows with Cephalexin. Indian J. Vet. Med. 20, 97-98.

WHIST, A. C., O. ØSTERAS (2007): Associations between somatic cell counts at calving or prior to dry-off and clinical mastitis in the remaining or subsequent lactation. J. Dairy Res. 74, 66-73.

DOI: $10.1017 / \mathrm{S} 0022029906002172$

WINDIG, J. J., W. OUWELTJES, J. TEN NAPEL, G. DE JONG, R. F. VEERKAMP, Y. DE HAAS (2010): Combining somatic cell count traits for optimal selection against mastitis. J. Dairy Sci. 93, 1690-1701.

DOI: $10.3168 /$ jds.2009-2052

ZECCONI, A., G. ZANIRATO (2013): Mastitis control for a sustainable dairy farm (diVet, GeSan, Eds.), p. 69 (in Received:23 July 2019

Accepted: 19 September 2019

TURINI, L., F. FRATINI, G. CONTE, B. TURCHI, D. CERRI, F. BERTELLONI, F. BONELLI: Procjena standardnog protokola zasušivanja mliječnih krava na temelju usporedbe dvaju različitih komercijalnih antimikrobnih preparata. Vet. arhiv 90, 217-224, 2020.

\section{SAŽETAK}

Cilj ovoga istraživanja bio je procijeniti učinke dva komercijalna antibiotika za zasušivanje koji se primjenjuju pri zasušivanju mliječnih krava. Uključeno je 95 krava frizijske pasmine i 380 četvrti vimena. Na temelju broja somatskih stanica krave su podijeljene u kontrolnu skupinu i skupinu sa supkliničkim mastitisom. Primijenjeni su Kalifornijski test za mastitis ocjena vrha sisa. Četvrti vimena su nasumično tretirane kloksacilinom i ampicilinom (TA) ili cefaleksinom (TB). Učinak terapije (TA u odnosu na TB) procijenjen je hi-kvadrat testom temeljenim na Wald-ovoj procjeni. Zaštitni i terapijski učinci TA-a u odnosu na TB procijenjeni su Kruskall-Wallisovim testom. TB je pokazao statistički znakovit terapijski učinak u kontrolnoj skupini, koji bi mogao biti povezan s farmakološkom aktivnošću dvaju antibiotika. Također, skupina sa supkliničkim mastitisom najčešće je imala više zahvaćenih četvrtina vimena u usporedbi s kontrolnom skupinom, što je vodilo pogoršanju unatoč terapiji. Zaključeno je da bi naglo zasušivanje, te korištenje Kalifornijskog testa za mastitis, ocjena vrha sisa, procjena broja somatskih stanica i podataka o mikrobnom statusu stada mogli biti ključni za učinkovit standardni protokol zasušenja na farmama mliječnih krava. S obzirom na populacije bakterija u stadu I korištenja TA i TB mogu se uključiti u protokol zasušivanja krava.

Ključne riječi: veterinarstvo; mliječne krave; mastitis; suhostaj; terapija pri zasušivanju 